Krzysztof Kościelniak

Jagiellonian University in Krakow

\title{
Arabic Culture of the Melchite Church in the early Middle Ages $\left(7^{\text {th }}-11^{\text {th }}\right.$ Centuries $)$
}

Christians that were loyal to the orthodoxy of the Chalcedony ecumenical Council (451) were named as "Melchites" by Heterodox monophysites, that is Copts in Egypt and Jacobits in Syria. Before the Moslem conquest the Melchite were mainly connected with Grecian culture, although they became influenced by the Arabic and Syriac environment. ${ }^{1}$

${ }^{1}$ Regarding Arabic Christianity before Muhammad, it is worth mention that a considerable number of Christian, Arabs in Pre-Islamic times is testified by many historic sources. The Church there was well organized; possessed it's own hierarchy, metropolis and monasteries. Vgl. J. Spencer Trimingham, Christianity among the Arabs in Pre-Islamic time, London-New York 1979; K. Kościelniak, Quelques remarques sur la littérarure pré-islamique arabe chrétienne, "Rocznik Orientalistyczny" 57:2004, pp. 69-76; the same, XX wieków chrześcijaństwa w kulturze arabskiej, vol. I, Kraków 2000; the same, Chrześcijańskie piśmiennictwo arabskie przed Mahometem i jego wptyw na islam, "Analecta Cracoviensia" 35:2003, pp. 329-343; the same, Chrześcijaństwo wśród nomadów arabskich na pograniczach Palestyny do aneksji Syrii, [in:] A. Abbas (ed.), Palestyna, dawniej i dziś. Materiały Interdyscyplinarnej Konferencji Naukowej zorganizowanej w Poznaniu, 19-20 listopada 2001 przez Katedrę Orientalistyki Uniwersytetu im. A. Mickiewicza, Poznań 2002, pp. 67-78; H. Charles, Le christianisme des arabes nomades sur le limes et dans le désert syro-mésopotamien aux alentours de l'Hégire, Paris 1936; F. Nau, Les Arabes chrétiens de Mésopotamie et de la Syrie du VII' au VIII siècle, Paris 1933; R. Devreesse, Arabes-Perses et Arabes-Romains, Lakhides et Ghassanides, "Vivre et penser" 2:1942, pp. 263-307; the same, Le christiansime dans la péninsule sinaïtique des origines à l'arrivée des musulmans, "Revue biblique" 49:1940, pp. 205-223; R. Dussaud, La pénétration des arabes en Syrie avant l'islam, Paris 1955; C. D. G. Müller, Kirche und Mission unter den Arabern in vorislamischer Zeit, Tübingen 1967; K. Samir, La culture arabe chrétienne ancienne en interaction avec la pensée arabe musulmane, "Islamochristiana" 8:1982, pp. 1-35; I. Shahid, Byzantium and the Arabs in the Fifth Century, Washington 1989; the same, Byzantium and the Arabs in the Fourth Century, Washington 1984; the same, Byzantium and the Semitic Orient Before the Rise of Islam, London 1988; the same, Ghassānid and Umayyad structures: A case of «Byzance après Byzance», [in:] La Syrie de Byzance a l'islam VII ${ }^{e}$-VIII' siècles. Actes 
The Moslem conquest of Syria (636) took the Melkite homeland out of Byzantine control and placed it under the occupation of the Arab invaders. Although the Byzantine cultural influence, the Greek language and culture remained important for the Melkites, Melkite tradition became systematically fused with the Arabic language and culture. ${ }^{2}$

\section{From Grecian to Arabic culture}

Which way was the Melchite Church connected with the Byzantium enriched Arabic culture? In a concept antiquity, the Greeks had a tendency to consider that anyone not Greek-speaking was a barbarian. As well as in the epoch of Christian Byzantium, Greek was the international language of the Middle East. Than the Muslim conquest of Syria and Egypt (634-641) created a cutting of from Byzantium of tree antique Melchite patriarchies: Antioch, Jerusalem and Alexandria. The Arabic language first changed to Greek, and then began the process of substituting Grecian culture. Arabic became the language of science and poetry. The Melchites had to accepted this situation but they assumed an attitude of defence like the Persians. Guarding their cultural autonomy and being proud of their history, they wrote both in language of their ancient heritage and in Arabic. Their window on the world became Arabic: if some Melchite scientist wished achieve success he had to know the official language of the caliphate. ${ }^{3}$

In respect of culture and the epoch, it could be named the age of the transformation. Christians in the Middle East and Egypt got caught up in the strong whirl of Arabization. This process was being reinforced more and more by using Arabic in the schools and the caliphate administration.

The Antioch, Alexandria and Edessa ancient Christian theological schools lived only in the memory from the point of view of their earlier magnificence. In the $8^{\text {th }}$ and $9^{\text {th }}$ centuries, the monasteries of St. Catherine in Sinai, St. Saba in Palestine and St. Symons in Syria tried to continue their Grecian traditions. Yet Arabic culture began to influence this Christian environment as well. First the communications Arabic language began to dominate among Melchites lived in Baghdad, then in Mesopotamia and North Syria. ${ }^{4}$

du Colloque international Lyon - Maison de l'Orient Méditerranéen, Paris - Institut du Monde Arabe 11-15 septembre 1990, ed. P. Canivet, J.-P. Rey-Coquais, Damas 1992, pp. 299-307.

${ }^{2}$ This article contains researches from my publication: From Grecian to Arabic. The Contribution of the Melchite Church to Arabic Culture in the early Middle Ages (VII ${ }^{\text {th }}-X^{\text {th }}$ Centuries), "Analecta Cracovienisa" 12 (2006-2007) 483-495.

${ }^{3}$ D. Gutas, Greek thought Arabic culture: the Graeco-Arabic translation movement in Bagdad and early 'Abbasid society (2 ${ }^{\text {nd }}-4^{\text {th }} / 8^{\text {th }}-10^{\text {th }}$ centuries), London 1998; M. Allard, Les Chrétiens à Bagdad, "Arabica" 9:1962, pp. 375-388.

${ }^{4}$ J.-M. Fiey, Chrétiens syriaques sous les Abbasides surtout à Bagdad (749-1258), Louvain 1980 (Corpus scriptorum christianorum orientalium, 420); L. Massignon, La politique 
In Syria to times Muslim conquests was bilingualism. In cities Byzantine civil servants and inhabitants in general used Greek. But the peasants used various dialects of the Aramaic (Syriac) language. After the Muslim conquest the situation underwent a change. Greek quite quickly vanished in cities but the process of withdrawing Syriac from villages was slower. The arabization was still an unusually progressive phenomena, and as early as the second half of the $8^{\text {th }}$ century Melchites began to use Arabic in their theology. Then a Melchite theologian who wrote in Arabic, Theodore Abū Qurra (about 750-830) became bishop of Harrān. However this author expressed more naturally his theological ideas in Greek than in Arabic. ${ }^{5}$

It's accepted that at the end of $8^{\text {th }}$ century, Arabic became the dominant language in the Melchite patriarchies. It was not only the common communication language, but it entered the church. The Melchite hierarchy sometimes used Arabic more than Greek, which testified to the fact that in the $4^{\text {th }}$ ecumenical Council in Constantinople (869-870), the Melchite bishop Thomas from

islamo-chrétienne des scribes nestoriens de Deir Qunna à la cour de Bagdad au IXe siècle de notre ère, "Vivre et penser" 2:1942, pp. 7-14; M. Canard, Bagdad au IVe siècle de l'Hégire (Xe siècle de l'ère chrétienne), "Arabica” 9:1962, pp. 267-287.

${ }^{5}$ For more information about this author and his creativity see: I. Dick, Un continuateur de saint Jean Damascène, Théodore Abu Qurra évêque melchite de Harran, la personne et son milieu, "Proche Orient Chrétien" 12:1962, pp. 209-233, 319-332; "Proche Orient Chrétien" 13:1963, pp. 114-129; I. Dick, Traité du culte des icons. Introduction et texte critique, Junieh 1986; A. Th. Khoury, Les théologiens byzantins et l'islam, Louvain 1969, pp. 83-105; A. Guillaume, Theodore Abu Qurra as Apologist, "The Muslim World" 15:1925, pp. 42-51; E. Hammerschmidt, Einige philosophisch-theologische Grundbegriffe bei Leontios von Byzanz, Johannes von Damaskus und Theodor Abu Qurra, "Ostkirchliche Studien" 4:1955, pp. 147-154; N. Akinian, Theodor Abuqurra und Nana der Syrer in Armenien und die Armenische Übersetzung des Kommentars des Nana zum Evangelium des hl. Johannes, "Handes amsorya" 36:1922, pp. 192-205; H. G. Beck, Kirche und theologische Literatur im byzantinischen Reich, Freiburg 1959, pp. 488-489; O. Bardenhewer, Geschichte der altkirchlichen Literatur, vol. V, Freiburg 1932, pp. 65-66; A. S. Tritton, The Bible Text of Theodore Abu Kurra, "The Journal of Theological Studies" 34: 1933, pp. 52-54; G. Graf, Geschichte der christlichen arabischen Literatur, vol. II, Die Schriftsteller bis zum Mitte des 15. Jahrhunderts, Città del Vaticano 1947, pp. 7-26; A. Th. Khoury, Les Théologiens byzantins et l'Islam. Textes et auteurs (VIII ${ }^{e}-X I I I^{e}$ s.), Louvain 1969², pp. 83-105; A. Th. Khoury, Der theologische Streit der Byzantiner mit dem Islam, Paderborn 1969, pp. 18-20; A. Th. Khoury, Apologétique byzantine contre l'Islam (VIII -XIII siècle), "Proche Orient Chrétien" 29:1979, pp. 242-300; 30:1980, pp. 132-174; 32:1982, pp. 14-49; S. H. Griffith, The Controversial Theology of Theodore Abu Qurrah (c. 750-c. 820), a Methodological, Comparative Study in Christian Arabic Literature, Ph. D. Dissertation, Catholic University of America, Washington D.C. 1978 (Ann Arbor, Michigan: University Microfilms, 78-1987); S. H. Griffith, Theodore Abu Qurrah's Arabic Tract on the Christian Practice of Venerating Images, "The Journal of the American Oriental Society" 105:1985, pp. 53-73; K. Samir, Abü Qurrah et les Maronites, "Proche Orient Chrétien" 41:1991, pp. 25-33; K. Samir, Le traité sur les icônes d'Abü Qurrah mentionné par Eutychius, "Orientalia Chrustiana Periodica" 58:1992, pp. 461-474; P. Pizzo, L'islam e musulmani nella difesa delle icone di Teodoro Abu Qurrah, "Parole de l'Orient" 22: 1998, pp. 667-676. 
Tyr communicated his speech through an interpreter. It's considered that the oldest - preserved Christian Arabic manuscript - up to the present day is SCHOTT-REINHARDT $n r 438$ kept in the university Library of Heidelberg. This papyrus, which contains some Muslim-Christian controversies, is dated to the first middle of $8^{\text {th }}$ century. The stylistic analysis of this fragment, shows that the text was written by an Arabic Christian. ${ }^{6}$ The research of scientist confirms the early relations between the formed Arabic and Christianity as represented by monastic communities. ${ }^{7}$

At the beginning of the $9^{\text {th }}$ century in the Syriac cities like Damas and Homs, Arabic became the language of Melchite inhabitants. On the other hand the Melchite monasteries founded in the deserts were often neighbours of the Bedouins, nomadic Arab tribesmen of the desert of Syria. That way in these years the monasteries St. Saba, St. Chariton and above all St. Catherine in Sinai were the caretakers of orthodoxy expressed in Arabic. ${ }^{8}$ Of course up until the presented epoch treatises have been written in Greek. However from the beginning of the $9^{\text {th }}$ century then were works written by monks with a knowledge of Greek, that is written a decided minority of monastic authors. The Christian-Arabic manuscripts were found in the Melchite monasteries among other famous things like VAT. ARAB. $n r 71$ that contains hagiography dated $885 .{ }^{9}$

Polemics with Islam, Christian apologies and Christological arguments in the context of the arabization of caliphate, caused a consolidation of Christian-Arabic theological terminology. It's amazing especially the expression of the mystery of the Trinity: the union of three people, the Father, Son and Holy Spirit in one God..$^{10}$ Contemporary Christian-Arabic theologians use for the designation of God's nature, the term تبيع tabì'a. Meanwhile the Christian-Arabic thought in the Middle Ages possessed several equivalent words to determine this reality. Sa'īd ibn Bitrīq wrote:

$$
11 \text { الآب و الابن و الروح القدس كيان و احد في ثلاثة اقانيم جو هر واحد طبيعة واحدة }
$$

The Father, Son and Holy Spirit are the unity in three hypostasis, one substance and one nature.

${ }^{6}$ G. Graf, Zwei Disputationen zwischen Muslimen und Christen, Heidelberg 1934, pp. 1-31.

${ }^{7}$ S. M. Griffith, The arabic Account of 'Abd al-Masih an-Nagrani al-Ghasani, "Le Muséon" 98:1985, pp. 331-374; I. Dick, La passion de Saint Antoine Ruwah, "Le Muséon" 74:1961, pp. 109-133.

${ }^{8}$ S. H. Griffith, Greek into Arabic: Life and Letters in the Monasteries of Palestine in the ninth Century. The Example of the Summa Theologiae Arabica, "Byzantion" 56:1986, pp. 117-138.

${ }^{9} \mathrm{~J}$. Nasrallah, R. Haddad, Histoire du mouvement littéraire dans l'Église Melchite du Ve au XX siècle Histoire du mouvement littéraire dans l'Église Melchite du Ve au XX siècle. Contribution à l'étude de la literature arabe chrétienne, part II.2, Paris 1979, pp. 48-49, 95.

${ }^{10} \mathrm{R}$. Haddad, Trinité divine chez le théologiens arabes, Paris 1985, pp. 161-185.

${ }^{11}$ Eutychii patriarchae Alexandrini annales, ed. L. Cheikho, vol. I, Berytii 1906, p. 146 (Corpus Scriptorum Christianorum Orientalium, 50). 
Similarly to a lot of other Christian Arabic-speaking authors (e.g., Ibn

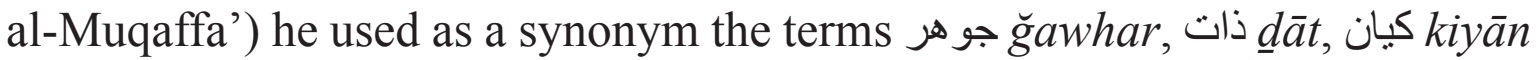
to determine the nature of God. ${ }^{12}$ Therefore one should be careful as Christian Theologians, often similar Arabic words meant something quite different than their equivalents in the Muslim theological language. ${ }^{13}$

Within this particular epoch appeared two types of Melchite literature. The first group included works written in classic Arabic. There belonged above all to the translations of the Grecian heritage of a wide range of philosophy and medicine. This literature was created for the scientific elite that included both Christian and Muslim scientists and scholars. The second kind of Melchite writing embraced hagiographical, liturgical and ascetic treatises. These manuals were for the benefit of Christian people. These addresses had influence on the style of Melchite works. According to necessity there were created either as bilingual (Arabic-Grecian) or trilingual (Arabic-Grecian-Syrian) treatises. ${ }^{14}$ One can say that used in this way, Arabic wasn't a new language but life-modifying fusha (classic Arabic). ${ }^{15}$ Anyway for some groups of Melchites, particularly there with contacts within the Syriac culture, classic Arabic was as equally difficult as Greek. ${ }^{16}$

\section{The importance of Melchite monasteries for Arabic culture}

The enriching influence of the Arabic culture on that Melchite community was accomplished in the first place through the activity of monasteries. Yet in the time of the conquest the monastic style of living was popular within the territory stretching from Syria to Egypt. The eremites were hold in high esteem. Although Quran (IX, 34) expresses the critical opinion about the Christian-monastic life, ${ }^{17}$ however as early as in the first half of the $7^{\text {th }}$ century, caliph Abu

${ }^{12}$ R. Haddad, Trinité divine chez le théologiens arabes..., s. 162-163.

${ }^{13}$ Ch.-J. Ledit, Two interesting christian-arabic usage, "Journal of Semitic Studies" 2:1957, pp. 360-365.

${ }^{14} \mathrm{~J}$. Nasrallah, R. Haddad, Histoire du mouvement littéraire dans l'Église Melchite du Ve au $X X$ siècle..., part II/2, p. 40.

${ }^{15} \mathrm{~J}$. Blau, A Grammar of christian arabic based mainly on south-palestinian texts from the first millennium, Louvain 1966-1967 (Corpus Scriptorum Christianorum Orientalium, 267, 276. Subsidia, 27, 28, 29); J. Haddad, La Trinité divine chez les théologiens arabes..., pp. 15-18; G. Graf, Der Sprachgebrauch der ältesten christlisch-arabischen Literatur. Ein Beitrag zur Geschichte des Vulgär-arabisch, Leipzig 1905; the same, Verzeichnis arabischer kirchlicher Termini, "Corpus Scriptorum Christianorum Orientalium" 147, Louvain 1954; J. Fück, Arabiyya. Recherches sur l'histoire de la langue et du style arabe, Paris 1955, pp. 87-96.

${ }^{16} \mathrm{~J}$. Nasrallah, R. Haddad, Histoire du mouvement littéraire dans l'Église Melchite du Ve au XX siècle..., part II.2, p. 41.

${ }^{17}$ IX, 34: "Believers, many are the rabbis and the monks who defraud men of their possessions and debar people from the path of Allah." The Quran. An English Translation of the Meaning 
Bakr (632-634) ordered considerate treatment of monks. Up to beginning of the VIII ${ }^{\text {th }}$ century, the monasteries had exemption from taxes. Monasticism also influenced the forming of Moslem ascetics. ${ }^{18}$ Despite having been well treated in the first century of the Muslim's presence in Middle East, several Melchite monasteries in Syria were afflicted by persecution. For example in the mountains Marde were completely destroyed two monasteries and the eremites were killed being allegedly of collaboration with Persians. ${ }^{19}$

Doubtless the Moslem conquest and preceding it, the Persian occupation, were leading to a confusion in the Melchite Church's structure. The crisis took in monasticism and initially the number of the taking orders was waning more and more rapidly. One misfortune followed another. For lack of monastic vocations some monasteries had to be liquidated. Even the biggest and the most flourishing monastic complex in Syria, the monastery St. Simon Stilite (Qal'at Sim 'ān) had at this time a severe crisis of vocations. In organisation of Muslim society the monks were becoming less and less necessary. ${ }^{20}$ The Melchite monasteries in the South (Syria, Sinai) were situated the desert. Luckily the almost absolute separation of these monasteries was always the main force of attraction for Christians, having wanted to realize the ideals of the Gospel. In the monasteries situated in deserts the crisis of vocation was less intensive. The eremites devoted themselves to noble causes: prayer, study, liturgy, the serving of the sacraments and working in gardens. They knew, as well Greek, Syriac and Arabic. In point of fact, the monks first translated the Bible, patristic and philosophical thought etc. from Greek into Arabic. ${ }^{21}$ There have also been the monastic vocations among Arabs: probably they were the principal translators of the Grecian heritage. Among the Melchite monasteries, the most eminent were the monastery of St. Catherine in Sinai and the monastery St. Saba in Palestine. ${ }^{22}$

Soon after the Muslim conquest the monks from the monastery of St. Catherine obtained from the Arabic conquerors a guarantee of freedom of worship and accommodation of pilgrims. But the monks had lots of problems with Bedouins

of the Quran, ed. M. Y. Zayid, Beirut 1980, p. 135.

${ }^{18} \mathrm{O}$. Livne-Kafri, Early Muslim ascetics and the world of Christian monasticism, "Jerusalem Studies in Arabic and Islam" 20:1996, pp. 105-129.

${ }^{19}$ Chronique de Michael le Syrien, Patriarche Jacobite d'Antioche, 1166-1199 A.D., ed. J.-B. Chabot, vol. II, Paris 1901, p. 419; S. H. Griffith, Michael, the martyr and monk of Mar Sabas monastery, at the court of the Caliph 'Abd al-Malik; Christian apologetics and martyrology in the early Islamic period, "Aram Periodical” 6: 1994, pp. 115-148.

${ }^{20} \mathrm{G}$. Tchalenko, Villages antiques de la Syrie du Nord. Le massif du Bélus à l'époche romaine, vol. I-III, Paris 1953-1958.

${ }^{21} \mathrm{~J}$. Nasrallah, R. Haddad, Histoire du mouvement littéraire dans l'Église Melchite du Ve au XX siècle..., part II.1, p. 62.

${ }^{22}$ The other famous monasteries of the Melchite Church were the monasteries ST. Chariton, St. Theodosius, St. Euthymius and St. Anastasius. 
who lived in the deserted region around the monastery. The nomads often looked jealously this rich monastery, which is why it was sometimes robbed. In spite of being attacked St. Catherine's monastery the monks always prepared place for the reception of many pilgrims. From time to time there were even 600-800 people. ${ }^{23}$ St. Catherine's monastery had it's own library and scriptorium but we don't have a date for their foundation. They were rewritten and collected liturgical texts, the rules of monastic monastic life, Psalters and Gospel texts. Sometimes the monks from another monastery were of some help rewriting the theological texts for use in St. Catherine's monastery. Still the Bedouin attacks themselves with such regularity, that a lot of manuscripts were destroyed and in some period this monastery was abandoned. However numerous manuscripts have remained, the oldest of which is dated back to $\mathrm{VI}^{\text {th }}$ century. ${ }^{24}$

It is estimated that in the Muslim conquest of the Palestinian-Judean Desert, there was an unusual development of Melchite monasticism because there were about 130 monasteries. ${ }^{25}$ Among these there was a second famous Melchite monastery - St. Saba (Mār Sābā). This monastery had a huge influence not only in Palestine but also the whole of the Middle East. ${ }^{26}$ St. Saba's monastery played a significant role in the theological disputes and the religio-political crisises like monphisitism, orygenism, monotheletism and iconoclasm. In a document, which was sent to the fathers of Lateran's synod in 649 from the monks of the Palestinian monasteries initially signed by the superior of Mār Sābā:

Joannes abba presbyter monasterii patris nostri sancti Sabbae, postulans manu subscripsi. ${ }^{27}$

The historical sources inform us that thank the splendid activity of St. Saba's monastery. Mār Sābā enjoyed fame and a good reputation through out the Christian world. The members arrived from almost all catholic countries. It's interesting that the monks prayed in their own languages, which - according to

${ }^{23}$ J. Pargoire, L'Église byzantine de 527 a 847, New York 1971², p. 239; J. Galey, Sinai and the Monastery of St. Catherine, London 1979; R. Solzbacher, Mönche, Pilger, Sarazenen. Studien zum Frühchristentum auf südlichen Sinaihabinsel, Altenberge 1989; H. Leclerq, Sinai, [in:] Dictionnaire d'archéologie chrétienne et de liturgie, vol. XV, Paris 1953, pp. 1469-1490.

${ }^{24}$ L. Prévost, Le Sinaï hier-aujourd'hui. Étude topographique, biblique, historique, archéologique, Paris 1937, p. 109.

${ }^{25} \mathrm{G}$. Troupeau, Kościoły i chrześcijanie na obszarze Wschodu muzułmańskiego, [in:] Historia chrześcijaństwa. Religia - kultura - polityka, vol. IV: Biskupi, mnisi i cesarze 610 - 1054, ed. J.-M. Mayer, Warszawa 1999, p. 335.

${ }^{26}$ J. Leroy, Moine et monastères du Proche Orient, Paris 1958, pp. 91-121; Y. Hirschfeld, The Judean Desert monasteries in the Byzantine Period, New Haven-London 1992; J. Patrich, Sabas, leader of Palestinian monasticism: a comparative study in Eastern monasticism fourth to seventh centuries, Washington 1994.

${ }^{27}$ Libellus monachorum - Secretarius II, Epistolae et decreta Martini papae I, [in:] Sacrorum conciliorum nova et amplissima collectio, ed. J. D. Mansi, vol. X, Lipsiae 1763, p. 909. 
biographer Cyril from Scitopolis - was in conformity with St. Saba himself. ${ }^{28}$ In respect of Mār Sābā's nationalities Melchites predominated from Palestine, Syria and the Greeks from the Middle East. A lot of Arabic texts originated in Mār Sābā. ${ }^{29}$ Even though Christian Arabic is full of dialectical forms and different from classic Arabic, which was worked out by the Muslim grammarians, there is no doubt that the use of the Arabic language by the ecclesiastical writers contributed to the grounding the Arabic culture in the Middle East. ${ }^{30}$

The end of the golden age of Mār Sābā took place on the 20 march 757 when Bedouins set fire to the monastery. As a result, not only was a considerable part of the buildings destroyed, but also were 20 monks suffocated. ${ }^{31} \mathrm{~A}$ few years later the monks in Mār Sābā were touched by a horrible plague. A monk of the St. Sabas monastery, Leontius from Damas was written that during this epidemic two or tree monks had passed away daily. Shortly after the disaster of the plague, the reborn monastery was touched by another misfortune. In Theophanes Chronographia we find out, that between 808 and 813 a civil war among the sons of the caliph Hārūn ar-Rašī came about and as a result, some Melchite monasteries suffered a great deal during this conflict. Besides Mār Sābā the monasteries of St. Chariton, St. Euthymius, and St. Theodosius was robbed and destroyed at this time. ${ }^{32}$

${ }^{28}$ Leben des Sabas, [in:] Kyrillos von Skythopolis, ed. E. Schwartz, Leipzig 1939, pp. 85-200; N. Heutger, Sabas, [in:] Biographisch-bibliographischen Kirchenlexikon, ed. F. W. Bartz, vol. VIII, München 2002, pp. 1135-1136; H. Leclerq, S. Sabas, [in:] Dictionnaire d'archéologie chrétienne et de liturgie, vol. XV, Paris 1953, pp. 189-211.

${ }^{29}$ A. Ehrhard, Das griechische Kloster Mar Saba in Palästina, seine Geschichte und seine literarischen Denkmäler, "Römische Quartalschrift" 7:1893, pp. 32-79; S. Vailhé, Les écrivains de Mār Sabas, "Echos d'Orient. Revue d'histoire de géographie et de liturgie orientales" 1:1898, pp. 1-11, 33-46; the same, Le monastère de Saint-Sabas, "Echos d'Orient. Revue d'histoire de géographie et de liturgie orientales“ 2: 1899, pp. 332-341; H. Bagatti, L'Église de la gentilité en Palestine, Jérusalem 1968, pp. 83-85; P. V. Corbo, L'ambiente materiale della vita die monaci di Palestina nel periodo bizantino, Roma 1956, pp. 215-257; J. J. Nasrallah, R. Haddad, Histoire du mouvement littéraire dans l'Église Melchite du Ve au XX siècle ..., part II, vol. 1..., pp. 64-65; D. J. Chitty, Et les desert devint une cité: une introduction à l'étude du monachisme égyptien et palestinien dans l'Empire chrétien, Abbay de Bellefontaine 1980, pp. 212-216, 218-223, 230-231, 244-253, 277-279, 289-291, 303-304, 312, 331, 344-346; J. Phokylides, Ha Hiera Laura Saba, Alexandria 1927; P. W. von Keppler, Wanderfahrten und Wallfahrten im Orient, Freiburg 1922, pp. 296-301; A. J. Festugière, Les moines d'orient, vol. III.2, Paris 1962.

${ }^{30} \mathrm{~J}$. Blau, The importance of Middle Arabic Dialects for the History of Arabic, Jerusalem 1961; the same, A Grammar of Christian Arabic, Louvain 1966; H. Blanc, Studies on North Palestinian Arabic, Jerusalem 1953; G. Graf, Der Sprachgebrauch der ältesten christlich-arabischen Literatur, Leipzig 1905; J. Fück, Arabiyya. Rechercduringhes sur l'histoire de la langue et du style arabe, Paris 1955.

${ }^{31}$ R. P. Blake, Deux lacunes comblées dans la Passio XX monachorum Sabaitarum, "Analecta Bollandiana" $68: 1950$, pp. 27-43;

${ }^{32}$ Theophanis chronographia, ed. C. de Boor, vol. II, Lipsiae 1885, pp. 277-278, 282-283. 
In spite of being touched by the disasters, the Melchite monasteries survived following defeats to reorganize their structures. The monasteries St. Saba and St. Chariton remained the cultural centres in Jerusalem's patriarchate. From there originated the majority of the patriarchs.

The monasteries were therefore the authentic centres of culture. It's interesting that - according various sources - there were also visited by the Muslims. There were most often visits connected mainly with non-religious purposes like relaxing (because the monasteries were usually set in beautiful localization) tasting good wines (although it's forbidden in Islamic practice) and experiencing monastic hospitality. Sometimes Muslims visited Melchite monasteries for religions reasons. They admitted the beauty of the Christian liturgy during feats. We also possess information that the Melchite monastery in Al-Qusayr (Egypt) was visited with pleasure by the founder of Tulunide's dynasty Ahmad ibn Tūlūn (868-884). His biographer Al-Balawī (died about 900) noted down an opinion of monk:

Emir Ahmad ibn Tūlūn visited us very often. He shut himself in one of the monastic cells to meditate. He spoke with pleasure to a monk called - Antonius. ${ }^{33}$

Also Ahmad ibn Tūlūn's son, emir Khummarawāyh (884-896). They said, that he had liked meditating in front of the mosaics representing Jesus Christ, Mary - Mother of God and the twelve apostles. ${ }^{34}$

\section{The most outstanding Melchite authors writing in Arabic}

Among the numerous Melchite writers creating in Arabic, three authors especially draw our attention. Their works enrich our knowledge in fundamental way about the stormy history of the Middle East in the medieval period.

It's proper to begin their presentation from Agapius the bishop of Mambī $\breve{g}$, that is Mahbūb ibn Qunstantīn al-Mambiğ̄i (died 945). He left us a universal history - Kitāb al- 'Unwān. ${ }^{35}$ Although some contemporary scientists accuse it of a shortage of originality in the presentation of ancient history, Kitāb al-'Unwān was successful among Muslims in the Middle Ages in the Orient. For example Agapius' work, considered to be original, praised the erudite 'Alī ibn Husayn

33 'Abdallāh ibn Muhammad al-Balawī, Sìrat Ahmad Ibn Tūlūn, [in:] J. Nasrallah, R. Haddad, Histoire du mouvement littéraire dans l'Église Melchite du Ve au XXe siècle..., vol. III.1, p. 62.

${ }^{34}$ B. T. A. Evetts (ed.), The churches and monasteries of Egypt and some neighbouring countries attributed to Abu Salih the Armenian, Oxford 1895 (repr. Oxford 1969) pp. 49-51.

${ }^{35}$ Agapius episcopus Mabbugensis Historia universalis, ed. L. Cheikho, Berytii 1912 (Corpus scriptorum christianorum orientalium, 65); Kitāb al-'unwan. Histoire universelle écrite par Agapius (Mahboub) de Menbidj, ed. A. Vasiliev, Turnhout 1971². 
al-Mas' $\bar{u} \mathrm{~d} \overline{\mathbf{1}}$ (died 956$)^{36}$ and this history was quoted by another Muslim scientist Ibn Šaddād (died 1285). ${ }^{37}$ The version of Kitāb al-'Unwān which we have at our disposal nowadays, begins from the creation of the world and finishes in 780. In spite of not being original - an opinion still mentioned - because its didn't bring in the new information about the universal history, Kitāb al-'Unwān constitutes in some domains the one and only source of knowledge about the Melchite Church's organisation in the early Middle Ages. The remaining manuscripts comply with two partial chronological divisions. ${ }^{38}$

The following source more helpful to the study of early medieval history in the Middle East is Sa' '̄d ibn Bitrīq's annals. His work Kitāb at-tārīh al-mağmū' 'ala $t$-tāhqīq wa t-tasdīq named by the letter copiers Nazm al-ğawhar ${ }^{39}$ was dedicated doctor 'İsa, Bitrīq's brother. Sa'īd ibn Bitrīq (as the patriarch of Alexandria named Eutychius) was sometimes classified in Arabic-biographical writing as saheb at-tārīh. His annals present numerous facts in the ecclesiastical domain and a universal history. As the patriarch of Alexandria and in conformity with prevailing medieval historiographical principles, Sa'̄̄d ibn Bitrīq presented the facts from the creation of the world. He took over the following ecclesiastical problems and heresies which maintained beliefs contrary to the established teachings of the Church. The value of this annals is ambivalent because Bitrīq sometimes drew information from doubtful sources and legends. Next to uncertain facts we find in Nazm al-ğawhar lots of true information confirmed other sources.

Without any doubt the most solid and critical history left us, Yahyā ibn Sa'id from Antioch (Yahyā al-Antakī, XI century), was a severe criticism of Bitrīq's annals. Yahyā al-Antakī took up a difficult job in improving and continuing Nazm al-ğawhar. ${ }^{40}$ The value of his chronicle is hugely underestimated. One can say that this the one and only piece a critical Melchite evidence to

${ }^{36}$ Le livre de l'avertissement et de la revision [par] Maçoudi, ed. B. Carra de Vaux, Paris 1896, p. 212.

${ }^{37}$ Ibn Šaddād, A'lāq al-hatīra, ed. S. Dahhan, Dimašq 1963, pp. 129-187.

${ }^{38}$ See: Bodl.arab.christ.Nicoll 51, $1^{\circ}$ (Hunt 478); Sin.arab. $5801^{\circ}$ (z roku 989); 456, fol. $103-164^{\mathrm{v}}\left(13^{\text {th }} \mathrm{c}.\right)$; Nasrallah $80\left(17^{\text {th }} \mathrm{c}.\right)$, Saint-Sépulcre arab. $93\left(18^{\text {th }} \mathrm{c}.\right) 113-262$; Orientale $3\left(16^{\text {th }}\right.$ or $17^{\text {th }} \mathrm{c}$.), [in:] J. Nasrallah, R. Haddad, Histoire du mouvement littéraire dans l'Église Melchite $\mathrm{du} \mathrm{V}^{e}$ au $X X$ siècle..., part II/2, p. 52.

${ }^{39}$ Eutychii patriarchae Alexandrini annales, ed. L. Cheikho, vol. I, Berytii 1906 (Corpus scriptorum christianorum orientalium, 50), Eutychii patriarchae Alexandrini annales - accedunt annales Yahia Ibn Said Antiochensis, ed. L. Cheikho; B. Carra de Vaux, H. Zayyat, vol. II, Berytii 1909 (Corpus scriptorum christianorum orientalium, 51); Eutychii patriarchae Alexandrini Annales, in: Patrologiae cursus completus. Series Graeca, ed. J.-P. Migne, vol. CXI, pp. 907-1156.

${ }^{40}$ Yahyā al-Antakī, Cronache dell'Egitto Fatimide e dell'Impero Bizantino (937-1033), ed. B. Pirone, Milano 1997 (Di fronte e attraverso, 434); Histoire de Yahya-ibn-Sa 'id d'Antioche continuateur de Sa'id ibn Bitriq, ed. I. Kratchkovsky, A. Vasiliev, "Patrologia Orientalis" $23: 1988$, pp. 349-520. 
testify the full misfortunes of Christian history in the Middle East within the period 937-1033. Thanks to his work we are able to portray and understand Byzantine-Muslim relations, the politics of the caliphs, the role of Melchite patriarchs, the events of the cruel persecution of Christians during the rule of caliph Al-Hākim (996-1021), the cultural achievements of Christian s and the organizational problems of the Melchite Church. Paradoxically we aren't able to fix the dates of birth and death of this great historian. It's accepted that Yahyā al-Antakī was born about 980 and passed away about $1034 .{ }^{41}$

In conformity with the title of this article, it is necessary to conclude with the presentation of the contribution of Melchites to the Arabic culture at the end of $11^{\text {th }}$ century. Although the politics of the Fatymide caliphs were very tolerant like Al-Mu'izz (953-975) and Al-'Azīz (975-996), one of the most brutal persecutions of Christians took place just into Fatymide period under the rule of mad caliph Al-Hākim (996-1021) ${ }^{42}$ While the earlier persecutions of Christians (e.g., in Abbasids period) were of rather a temporary character, during Al-Hākim's governing period the anti-Christian laws were continuously executed for nine years. In this time of repressions and terror, the worst were the years between 1012-1014. Just when Al-Hākim ordered the systematic destruction of churches and monasteries. As a result of this action not only were hundreds of Christian temples utterly destroyed but also numerous invaluable monuments of Melchite art. Especially tragic was the destruction of the Church of the Holy Sepulchre in Jerusalem. The Egyptian caliph al-Hākim destroyed the church in 1009 and had the tomb hacked down to bedrock. ${ }^{43}$

${ }^{41}$ J. H. Forsyth, The Byzantine-Arab Chronicle (938-1034) of Yahya b. Sa'id al-Antaki, dissertation, University of Michigan 1977; M. Canard, Al-Antakī, in: Encyclopédie de l'islam, nouvelle éedition, vol. I, Leiden 1960, p. 531b-532a; G. Graf, Geschichte der christlichen arabischen Literatur, vol. II, Die Schriftsteller bis zum Mitte des 15. Jahrhunderts, Città del Vaticano 1947, pp. 49-50; J. Nasrallah, R. Haddad, Histoire du mouvement littéraire dans l'Église Melchite du Ve au XX siècle..., part III.1, pp. 167-175.

${ }^{42}$ S. A. Assaad, The Reign of al-Hakim bi amr Allah (386/996-411/1021): A Political Study, Beirut 1974.

${ }^{43}$ Yahyā al-Antakī wrote about this destruction:

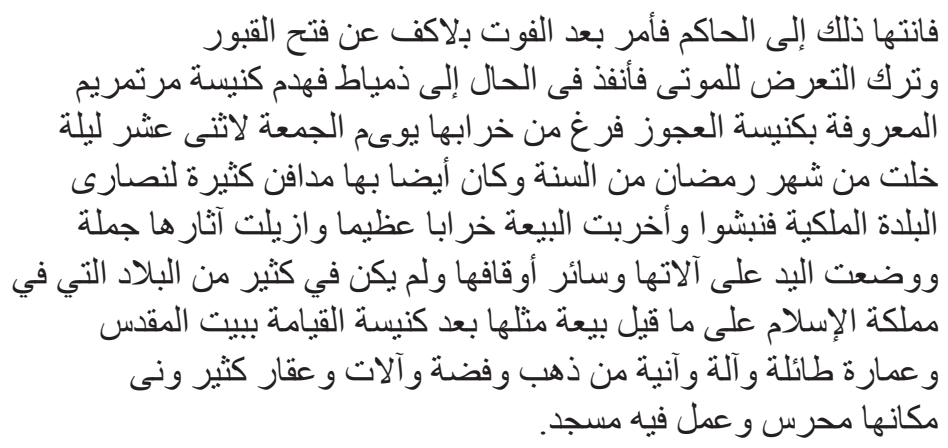

Histoire de Yahya-ibn-Sa'id d'Antioche continuateur de Sa 'id ibn Bitriq ..., pp. 495-496. 
From the History of the Patriarchs of the Coptic Church of Alexandria we know, that in these distressed years in Cairo, it was even forbidden celebrate any Holy Mass. During the al-Hākim persecutions, a lot of Christians apparently converted to Islam. ${ }^{44}$ According to Yahyā al-Antakī the conversions to Islam happened more often in the cities than in the country because in the towns, the persecution took the gravest form. ${ }^{45}$ Al-Hākim finished persecutions of Christian in about 1020 under the influence of the Melchite monk Salomon. But the dimension of the destructions were huge; as mentioned in History of the Patriarchs of the Coptic Church of Alexandria we are informed that Christians had to dedicate thirty years to rebuild and restore their churches. ${ }^{46}$ In some regions the Melchite Churches were unable to recreate their structures from before the al-Hākim's persecution. That way, in the next two centuries, the influences of Melchites on Arabic culture were considerably weakened.

${ }^{44}$ Y. Lev, Persecutions and Conversion to Islam in Eleventh-Century Egypt, "Asian and African Studies" 22:1988, pp. 73-91.

${ }^{45}$ Yahyā al-Antakī, Cronache dell'Egitto Fatimide e dell'Impero Bizantino (937-1033)..., pp. 309-312.

${ }^{46} \mathrm{~K}$. Kościelniak, Chrześcijaństwo wobec podbojów muzułmańskich do wypraw krzyżowych, [in:] W kręgu cywilizacji Pótksiężyca,6. Ogólnopolska Konferencja Arabistyczna Kraków, 14-15 maja 2002, red. B. Michalak-Pikulska, Kraków 2002, 204-205. 